\title{
POSKOLONIALITAS $^{1}$ DI NEGARA DUNIA KETIGA ${ }^{2}$
}

\author{
I Putu Hendra Mas Martayana \\ Universitas Pendidikan Ganesha \\ hendra.iputu@yahoo.co.id
}

\begin{abstract}
Abstrak
Melalui berbagai gambaran mengenai Timur yang aneh dan mistis, tidak beradab dan barbar, Barat secara terus menerus mengkonstruksi sebuah wacana yang menempatkan Timur sebagai inferior dan Barat sebagai superior. Dengan cara ini, Barat tidak hanya ingin mendominasi dunia non-Barat melalui imperialisme secara politis dan militer, tetapi, setelah bangsa-bangsa terjajah non-Barat memperoleh kemerdekaannya, Barat ingin tetap menjajah non-Barat melalui konstruksi wacana yang dianggap sah dan representatif untuk menggambarkan dunia non Barat. Namun demikian, menancap kuatnya wacana Barat di kepala orang Timur, mengakibatkan interaksi sosial keduanya menghasilkan representasi identitas Timur yang mendua, membenci sekaligus mencintai. Membenci karena Barat dianggap sumber depersonalisasi dan demoralisasi, mencintai karena Barat adalah inspirasi untuk menuju tatanan dunia modern yang beradab.
\end{abstract}

\section{Kata Kunci : Poskolonialitas, Identitas, Timur, Barat}

\begin{abstract}
Through different picture of the strange and mystical East, uncivilized and barbaric, the West continually constructing a discourse that put the East as inferior and the West as superior. In this way, the West did not just want to dominate the non-Western world through imperialism politically and military, but, after the colonial people of nonWestern gaining their independence, the West wants to keep colonize non-West through the construction of a discourse that is considered legitimate and representative to describe non-Western world. However, embeddied strong discourse of the West at the head of the East people, resulting in social interactions both produce an ambiguous representation of Eastern identity, hate once loved. Hate for the West is considered the source of depersonalization and demoralized, love for the West was the inspiration for leading modern civilized world order.
\end{abstract}

\section{Keywords : Postcoloniality, Identity, East, West}

\footnotetext{
1 Poskolonial adalah teori kritis tentang dominasi, hegemoni dan subordinasi Barat atas Timur. Teori ini muncul sebagai hasil pembacaan dan terinspirasi dari tokoh-tokoh post strukturalisme seperti Michele Foucault, Jean Paul Sartre dan tokoh posmodern seperti Jacques Derrida. Tiga tokoh kunci poskolonial dan dianggap sebagai nabinya teori ini di antaranya ; Edward Said (Orientalisme), Homi K. Babha (The Location of Culture), dan Gayatri Spivak (Can Sub-altern Speak?). Said adalah orang Palestina, sedangkan Gayatri orang India, keduanya bekerja sebagai pengajar sastra Inggris dan sastra komparasi di Universitas Columbia. Sedangkan Bhaba orang India yang bekerja sebagai pengajar sastra Inggris di Universitas Sussex. Khususnya Gayatri Spivak, dia adalah orang yang dipercaya menterjemahkan karya tokoh dekonstruksi Derrida yang berat itu yakni "on grammatology" ke dalam bahasa Inggris. Ketiganya adalah produk "Dunia Ketiga" yang bekerja dan berkarya dalam ruang lingkup studi literer universitas "Dunia Pertama”.

2 Negara Dunia Ketiga atau dalam pandangan Barat disebut sebagai The Developing Countries adalah negara-negara yang muncul pasca Perang Dunia II. Sentimen kebangsaan yang dimiliki bersifat cangkokan (imbricated) dan bertujuan mendudukan Barat sebagai "pendatang" dan pribumi sebagai "asli".
} 


\section{PENDAHULUAN}

Poskolonialitas bersinggungan dengan perdebatan mengenai pengalaman dalam berbagai jenisnya, yaitu migrasi, perbudakan, penindasan, resistensi, representasi, perbedaan, ras, gender, ruangtempat, subjektivitas, kekuasaan, subaltern, hibriditas dan kreolisasi ${ }^{3}$ (Barker, 2000: 389 ; Ashcrofft, 1995: 2 ; King, 2001:v-vi). Teori ini juga merespon wacana dominan imperialisme Eropa seperti sejarah, filsafat dan bahasa serta pengalamanpengalaman fundamental yang terangkum dalam ucapan dan tulisan. Cakupannya adalah seluruh khazanah sastra nasional yang pernah mengalami kekuasaan sejak awal kolonisasi hingga sekarang. Sastra yang dimaksudkan, di antaranya adalah Afrika, Australia, Bangladesh, Kanada, Karibia, India, Malta, Selandia Baru, Pakistan, Singapura,

3 Wacana kreolisasi dan bagaimana pertautan identitasnya di dunia liminal (antara Barat dan Timur) bisa disimak pada karya Pramoedya "Tetralogi Pulau Buru". Tokoh Minke diceritakan menjalin hubungan asmara dengan keturunan kreol, anak dari Nyai Ontosoroh dan tuan Milema bernama Annelies. Dengan demikian, kreol yang dimaksud di sini bisa berarti warga Hindia blasteran (orang-orang Indo).
Kepulauan Pasifik Selatan, Sri Lanka, Malaysia, dan Indonesia.

Tema-tema yang dikaji dalam poskolonial amat luas dan beragam, meliputi hampir seluruh aspek kebudayaan, di antaranya: politik, ekonomi, agama, ideologi, pendidikan, sejarah, antropologi, kesenian, etnisitas, bahasa, dan sastra. Dengan demikian, teori poskolonial melibatkan tiga pengertian, yaitu: a) abad berakhirnya penjajahan fisik di seluruh dunia, b) segala tulisan yang berkaitan dengan pengalamanpengalaman, dan c) teori-teori yang digunakan untuk menganalisis masalah-masalah pascakolonial (Sabbarwal, 1999: 34).

Wacana poskolonial berupaya menganalisis kenyataan historis tentang kolonialisme Eropa yang secara terus menerus membentuk hubungan antara Barat dan non-Barat setelah negara-negara bekas koloni memperoleh kemerdekaannya. Poskolonialisme menggambarkan proses resistensi dan rekonstruksi yang terus dilakukan oleh non-Barat. Wacana poskolonial berupaya 
mendekonstruksi watak binerisme ${ }^{4}$ yang biasanya digunakan untuk merekonstruksi perbedaan identitas ${ }^{5}$ antara hitam-putih, beradab-barbar, tradisional-modern, sang diri-sang lain (King, 2001: v-vi).

Koloni dan Kolonialisme: Intimitas Barat Tentang Timur

Kata koloni berasal dari bahasa Latin, colonia yang berarti sebuah perkampungan yang didiami oleh bangsa atau suku bangsa tertentu atau sekumpulan orang asing yang menempati suatu daerah tertentu di luar negeri (Ensiklopedi Nasional

4 Konsep oposisi biner mula-mula diteorisasikan oleh ahli bahasa Ferdinand de Saussure, tetapi Claude Levi Strauss (selanjutnya disebut ahli strukturalisme) lah yang menjadikannya berpengaruh. Baginya, oposisi biner adalah "the essence of sense making", yakni struktur yang mengatur sistem pemaknaan terhadap budaya dan dunia tempat hidup. Dengan demikian, oposisi biner merupakan produk dari budaya dan tidak alamiah, melainkan hasil dari sistem penandaan dan berfungsi menstruktur persepsi terhadap alam natural dan dunia sosial melalui penggolonganpenggolongan dan makna.

5 Dalam pandangan sosiologi keteraturan, warisan teori-teori sosiologi klasik, kelompok atau individu yang tidak termasuk ke dalam hitam atau putih, laki atau perempuan, benar atau salah adalah pihak yang harus dihilangkan, dimusnahkan karena mengganggu keselarasan dan keharmonisan sistem. Dan oleh sebab itu bisa mengganggu status quo dari pusat. Keberadaannya bisa mengakibatkan anomie, chaos, anarki. Dalam pandangan Foucaudian, kelompok ini harus dinormalisasi, didisiplinkan melalui sebuah wacana, dan Foucault menyebutnya sebagai "regime of truth".
Indonesia, 1997: 44). Jadi, koloni merupakan suatu tempat yang kosong yang kemudian didatangi oleh sekelompok orang dari bangsa tertentu dan kemudian menghuni tempat kosong tersebut. Pada perkembangan selanjutnya, orang tidak lagi mencari tempat kosong untuk membuat suatu perkampungan, tetapi mendatangi tempat yang sebelumnya sudah dihuni oleh sekelompok bangsa atau suku bangsa tertentu. Karena pendatang baru ini dalam segala hal lebih dominan, penduduk lama kedudukannya mulai tergeser, bahkan, lebih jauh lagi mulai tersingkir.

\section{Dengan terjadinya penempatan} daerah yang sebelumnya sudah dihuni oleh sekelompok bangsa atau suku bangsa tertentu itulah, kata kolonial, yang merupakan kata turunan dari kata koloni, diartikan menjadi penguasaan suatu wilayah atas wilayah lain, biasanya wilayah yang berada di seberang lautan. ${ }^{6}$ Dari

\footnotetext{
6 Pada kasus Eropa, semangat mencari daerah koloni di seberang lautan dipelopori oleh Spanyol dan Portugis. Di bawah nahkoda Bartholomeouz Diaz, Portugis berhasil menyisir pantai barat Afrika dan menemukan jalur pertemuan Samudera Atlantik dan Samudera Hindia di ujung selatan benua Afrika yang diberi nama “Tanjung Harapan" pada 1486. Spanyol di
} 
penguasaan wilayah baru itu, kemudian terjadi pengeksploitasian yang dilakukan dengan kekerasan dan tidak mempertimbangkan kepentingan atau perasaan orang lain (Mehling, 1978: 385).

Issac (dalam Naim, 1984: 6) membagi kolonisasi ke dalam dua jenis, yakni kolonisasi eksploitasi dan kolonisasi pemukiman. Kolonisasi eksploitasi biasanya hanya melibatkan sejumlah kecil pedagang, pejabat pemerintah, dan tentara yang dipindahkan dari negara ibu, sedangkan budak atau buruh kontrak dikumpulkan untuk penyediaan tenaga kerja yang diperlukan. Kolonisasi jenis kedua yakni kolonisasi pemukiman. Kolonisasi ini terjadi bila negara yang telah kokoh berdiri, progresif, dan berhasrat besar mengirim rombongan warga negaranya keluar negerinya, biasanya secara resmi, untuk bermukim di suatu lokasi

bawah Christopher Colombus menemukan kepulauan Bahama di Amerika tengah pada tahun 1492 dan mengawali kolonisasinya di benua baru itu. Dua tahun setelah penemuan Amerika oleh Spanyol, diadakan Perjanjian Tordhesilas (1494) antara Spanyol, Portugis dan Paus Roma. Perjanjian tersebut mengawali kolonisasi Eropa ke dunia Timur dengan semangat reconquista dan imperialisme kuno. tertentu. Daerah-daerah yang dipilih itu adalah daerah yang baru ditemukan atau negeri-negeri yang jarang penghuninya, yang penduduk aslinya begitu kecil jumlahnya, atau tingkat budayanya begitu rendah sehingga mereka memberikan perlawanan yang hampir tidak berarti terhadap masuknya para kolonis tersebut.

Kolonialisme tidak bisa dipisahkan dari imperialisme, yakni ambisi atau hasrat untuk memperluas kekuasaan secara politis dan mengukuhkan batas-batas negara. Said (1996b : 40) menyatakan 'imperialisme' berarti praktik, teori, dan sikap dari suatu pusat metropolitan yang menguasai wilayah yang jauh; kolonialisme yang hampir selalu merupakan konsekuensi imperialisme adalah dibangunnya pemukimanpemukiman di wilayah-wilayah yang jauh. ${ }^{7}$ Doyle (dalam Said, 1996b : 40)

\footnotetext{
7 Sikap terjajah terhadap penjajah penuh dengan ambivalensi sebagai akibat dari continuing effects kolonialisme. Ada rasa benci karena luka sejarah yang ditimbulkan, tetapi sekaligus juga rasa kagum (dan karena itu merindukannya, entah sadar atau tidak) karena superioritas peradaban yang (pernah) dipertontonkannya. Ada kecenderungan untuk mengkambinghitamkan masa lalu kolonial atas segala keterbelakangan dan keterpurukan pada masa kini, tetapi
} 
berpendapat bahwa imperialisme adalah proses atau kebijaksanaan untuk menegakkan atau mempertahankan imperium. Imperium adalah hubungan, formal maupun informal, bahwa suatu negara menguasai kedaulatan politik efektif dari suatu masyarakat politik lainnya. Hal ini bisa dicapai dengan paksa melalui kolaborasi politik, melalui ketergantungan ekonomi, dan sosial, atau budaya. ${ }^{8}$

Analisis wacana kolonialisme dirintis sebagai subdisiplin akademik oleh Edward Said dalam karyanya yang berjudul Orientalisme. Ia berhasil menunjukkan hubungan langsung antara bahasa dan bentukbentuk pengetahuan yang telah terjadi sepanjang sejarah

sekaligus juga berterima kasih kepadanya karena kekuatan-kekuatan koloniallah yang kemudian memungkinkan terbentuknya "negara bangsa".

8 Dua abad setelah Portugis dan Spanyol menancapkan kekuasaannya di wilayah Timur, negara-negara Eropa Barat seperti Inggris, Prancis dan Belanda muncul sebagai kekuatan baru menggantikan imperialisme kuno berbasis merkantilisme yang telah usang dengan imperialisme modern berbasis kapital. Inggris berkuasa atas India (termasuk Pakistan dan Bangladesh), Burma (sekarang bernama Myanmar), Malaysia, Singapura dan Brunei, sedangkan Prancis berkuasa di Indo-Cina. Batas kekuasaan keduanya dipisahkan oleh Thailand (Buffer State). Sedangkan Belanda menguasai Indonesia yang diberi nama Netherland Indies atau Hindia Belanda. imperialisme dan kolonialisme dan berkeyakinan bahwa konsep-konsep dan representasi yang digunakan dalam teks-teks novel, catatan perjalanan, memoar, dapat dianalisis untuk memahami ideologi kolonialisme yang berbeda-beda (Lazuardi, 2003: 1). Dalam analisisnya itu, Said mengadopsi metode yang digunakan Michele Foucault, bahwa orientalisme itu dibangun melalui konstruksi diskursif. Hal ini memberi dampak teoritis dalam karyanya. Pertama, Said menunjukkan bahwa ideologi tidak saja beroperasi melalui kesadaran, melainkan juga lewat barang praktis material. Kedua, ada jalinan-jalinan yang rumit dan kompleks antara politik dan ilmu pengetahuan; pengetahuan Barat, langsung atau tak langsung merupakan bentuk wacana kolonialisme. Ketiga, orientalisme bersifat self generating, artinya dikembangbiakan oleh dirinya sendiri. Hal terpenting di sini adalah pengetahuan Barat, teks-teksnya tidak hanya menciptakan pengetahuan, tetapi juga berisi 
deskripsi dari apa yang tampak dan apa yang senyatanya terjadi.

Konsep Edward Said mendapat koreksi dari Homi K. Bhaba yang memfokuskan diri pada klaim Said bahwa orientalisme itu selalu instrumental dan bekerja dengan sukses dalam bentuk-bentuk yang praktis. Bhaba menambahkan psikoanalisa pada analisis Said yang bekerja menurut kerangka Foucault. Ia membicarakan kemungkinan bahwa orientalisme itu bekerja pada tingkat yang berbeda, yaitu yang ia sebut sebagai "manifest orientalism", yakni suatu pengetahuan yang bersifat "saintik" tentang Timur dan "laten orientalism”, suatu ketidaksadaran nafsu fantasi. Ia menunjukkan bahwa wacana kolonialisme beroperasi tidak hanya melalui instrumen tertentu saja, tetapi juga menurut fantasi. Kesimpulannya, orientalisme tidak bisa didefinisikan secara sederhana menjadi hanya persoalan representasi. ${ }^{9}$ Orientalisme mungkin

9 Stuart Hall (tokoh kunci Cultural Studies dan pendiri New Left) membedakan proses representasi menjadi dua, pertama representasi mental; yaitu konsep tentang sesuatu yang ada di kepala (peta konseptualabstrak). Kedua, bahasa yang berperan penting dalam proses konstruksi makna, memang representasi, tetapi juga ikut bermain di dalam lapangan diskursif. Representasi bukanlah suatu entitas yang statis karena selalu berisi ucapan-ucapan baik yang tertulis maupun tidak dari pihak tertentu kepada pihak yang lain.

Pada sisi yang lain, Gayatri Spivak membicarakan pada kemungkinan "counter knowledges". Semangat sejarawan antikolonial sekarang menurutnya adalah untuk menuliskan sejarah mereka yang dikeluarkan "the voiceless, yang selama ini hanya menjadi objek dari pengetahuan dan fantasi kolonialisme. Secara umum ia menaruh perhatian dengan kelanjutan kekerasan epistemik yang dipraktikkan oleh pikiran orang Barat kepada orang Timur. Ia

konsep abstrak yang ada di kepala harus diterjemahkan ke dalam bahasa yang lazim supaya dapat menghubungkan konsep dan ide-ide tentang sesuatu dengan tanda dan simbol-simbol tertentu. Proses pertama memungkinkan untuk memaknai dunia dengan mengkonstruksi seperangkat rantai korespondensi antara sesuatu dengan sistem peta konseptual. Dalam proses kedua, kita mengkonstruksi seperangkat rantai korespondensi antara peta konseptual dengan bahasa atau simbol yang berfungsi merepresentasikan konsep-konsep tentang sesuatu. Hubungan antara peta konseptual dan bahasa adalah jantung dari produksi makna lewat bahasa. Proses yang menguhubungkan ketiga elemen ini secara bersama-sama itulah yang kita sebut representasi. 
menunjukkan bahwa sejarah bukanlah produksi fakta-fakta yang tidak menarik, tetapi sebuah wujud kekerasan epistemik, sebuah konstruksi representasi objek tertentu oleh pihak tertentu juga.

\section{Orientalisme : Membentuk Timur}

\section{ala Barat}

Konsep Barat (oksidentalisme)

dan Timur (orientalisme) tidak tergantung pada letak geografisnya, tetapi pada posisi seseorang itu berada, dari mana orang memandangnya karena pada dasarnya bumi ini bulat. Sebagai contoh, Indonesia dapat memandang Eropa sebagai Barat, dapat pula sebagai Timur. Jika seseorang berada di Indonesia dan menghadap ke Samudra Atlantik, Eropa ada di sebelah Barat. Sementara itu, kalau seseorang berada di Indonesia dan menghadap ke Samudra Pasifik, Eropa ada di sebelah Timur. Dengan demikian, yang dimaksud Barat dalam paham Orientalisme adalah mereka yang berkulit putih, sedangkan Timur adalah mereka yang berkulit berwarna.

$$
\text { Orientalisme }^{10}
$$

dengan demikian bisa dimaknai sebagai konstruksi historis terhadap masyarakat dan budaya Timur sebagai "sesuatu yang asing", seringkali bahkan dilihat sebagai sejenis alien atau objek yang indah dan eksotis. Akan tetapi, sebaliknya, Timur juga sering dianggap sebagai kasar, bodoh, barbaris, irrasional, bejat moral, kekanakkanakan,"berbeda". Orang-orang Timur ditampilkan sebagai mahluk yang mudah dikecoh, tidak mempunyai energi dan inisiatif, suka menjilat, berpura-pura, dan licik. Orang Timur adalah pembohongpembohong karatan, mereka malas, mencurigakan. Dengan sendirinya,

\footnotetext{
10 Para orientalis di dalam sejarah Indonesia bisa dipersamakan dengan indolog, yakni para peneliti, intelektual Belanda dengan spesialisasi bidang tertentu seperti arkeologi, sejarah, antropologi, filologi, filsafat, bahasa yang ditugaskan melakukan kajian demi kepentingan negeri penjajah. Beberapa dari para indolog yang namanya sudah tidak asing di telinga kaum akademisi Indonesia misalnya J.L.A Brandes (ahli bahasa Kawi) yang merekonstruksi sejarah Singosari memakai sumber kitab Pararaton: Katutura nira Ken Arok. Tulisannya terbit dengan judul "Pararaton (Ken Arok) of het Boek der Koningen van Tumapel en van Majapahit (1896) dalam VBG no. XLIX. Tugasnya dilanjutkan oleh $\mathrm{H}$. Kern yang memakai sumber pujasastra Negarakretagama berjudul "De Negarakretagama. OudJavaansch Lofdicht op Koning Hayam Wuruk van Majapahit" (1916). Kedua karya maestro itu disempurnakan oleh indolog lainnya yakni N.J Krom melalui tulisan "HindoeJavaansche Geschiedenis” (1926).
} 
Barat menganggap dirinya rasional dan berbudi luhur, "normal". Mereka adalah penalar yang cermat; semua pernyataannya mengenai fakta, bebas dari semua bentuk kekaburan. Ia adalah logikawan alami sekalipun mungkin ia tidak mempelajari logika; ia memiliki pembawaan yang skeptis dan menuntut bukti sebelum menerima kebenaran dari sesuatu ; intelegensinya yang terlatih bekerja laksana sebuah mesin (Said, 1996a: 49\&51). ${ }^{11}$ Dengan demikian, Orientalisme dapat dipahami sebagai wacana yang memperlihatkan perbedaan yang fundamental antara "kami orang Barat" dan "mereka orang Timur". Barat, dengan demikian memiliki legitimasi untuk

11 Cara berpikir Barat yang diwarnai dengan rasio, nalar dan logika, tidak bisa dilepaskan dari jejak triumvirat filosof Yunani, yakni Sokrates, Plato dan Aristoteles. Namun, runtuhnya Romawi diikuti pula oleh tercerabutnya filsafat Yunani dan digantikan oleh filsafat Kristen. Barat pada akhirnya terisolasi oleh kekuatan Islam berwujud kekhalifahan pasca Muhamad seperti khalifah Umayah (Damaskus-Syiria) dan Abbasyah (Bhagdad-Irak). Periode ini disebut sebagai abad pertengahan (era skolastik), namun ada pula yang menyebutnya sebagai abad kegelapan (The Dark Age). Pertemuan Barat dengan filsafat Yunani kembali terjadi secara tidak sengaja melalui Perang Salib (crusade war) 1091-1299. Mereka mengambilnya dari intelektual Islam di Jerusalem yang sebelumnya telah banyak menterjemahkan karya klasik Plato dan Aristoteles dari bahasa Yunani ke bahasa Arab. Hal ini menandai babak baru sejarah Eropa yang disebut dengan abad renaisan mengatur dan menguasi Timur. Dalihnya adalah Timur tidak bisa mengatur dirinya sendiri dan membebaskannya dari kebodohan. Timur yang lemah dan tidak berenergi membutuhkan Barat yang kuat. Timur direkonstruksi, disusun kembali, diukir, ringkasnya dilahirkan kembali.

Dari asumsi semacam itu, Orientalisme dapat dibahas dan dianalisis sebagai lembaga hukum untuk berurusan dengan dunia Timur dengan membuat pernyataanpernyataan tentangnya, melegalkan pandangan-pandangan tentangnya, mendeskripsikannya, dengan mengajarinya, menjadikannya sebagai tempat pemukiman, dan memerintahnya. Dengan kata lain, orientalisme adalah gaya Barat untuk mendominasi, menata kembali, dan menguasai Timur. Budaya Eropa memperoleh kekuatan dan identitasnya dengan cara menyandarkan dirinya kepada dunia Timur sebagai semacam wali atau pelindung, bahkan "diri" yang tersembunyi (Said, 1996a: 4). 


\section{Alienasi $^{12}$ dan Mimikri}

Penjajahan, selalu lebih banyak berdampak negatifnya daripada dampak positif terutama bagi manusia yang terjajah. Dampak negatif itu di antaranya menimbulkan depersonalisasi dan alienasi kultural sosial dan batin si manusia terjajah. Depersonalisasi penjajah atas si terjajah bukan hanya mengasingkan gagasan pencerahan tentang 'manusia', melainkan mengubah transparansi realitas sosial yang telah ada sebelumnya. Apabila tatanan historisitas Barat di suatu negara jajahan terganggu, yang lebih terganggu lagi adalah representasi fisik dan sosial subjek manusianya. Dalam kondisi penjajahan, humanitas yang natural akan berubah menjadi (ter)asing.

Alienasi kultural memusatkan diri pada ambivalensi identifikasi

\footnotetext{
12 Alienasi dalam teori poskolonial berbeda dengan alienasi dalam pandangan Marxisme. Alienasi ala Marx bersifat determinisme ekonomis yakni tersub-ordinasinya satu kelas oleh kelas lain karena persoalan "perut"; dan bahwa sejarahlah yang menentukan ide. Sedangkan alienasi poskolonial tidak hanya terjadi pada dimensi material yang esensial lalu dikontruksi secara sosial dan budaya melainkan juga pada tataran nilai,ide dan gagasan yang bersifat cangkokang (embeddied). Dengan kata lain, alienasi dalam kacamata poskolonial merupakan perluasan dan penajaman alienasi ala Marx.
}

fisik yang membuat manusia terjajah menderita karenanya. Seperti yang digambarkan Fanon (Bhabha, 1994: 42), tatapan manusia kulit putih dapat memporakporandakan manusia kulit hitam/ berwarna. Kulit berwarna yang sering dituduh sebagai primitive, memiliki defisiensi intelektual, ras rusak, kanibal, akhirnya menjadi membenci eksistensi dirinya. Oleh sebab itu, dalam manusia kulit berwarna selalu timbul hasrat untuk melarikan diri dari keberadaan dirinya. Orang kulit putih pada kasus itu bisa dianggap sebagai ahlinya dalam membuat orang kulit berwarna membenci identitas dirinya (Malcolm X dalam Synnott, 2003: 65).

Alienasi identitas telah membuat keberadaan seseorang menjadi terbelah, membayangbayangi dirinya sebagai manusia terjajah yang merupakan refleksi dari kegelapannya. Karena itu, manusia terjajah memiliki hasrat untuk keluar, untuk melarikan diri dari kondisi tersebut, dan masuk ke dalam 'sang lain' yang diidealkan. Untuk menjadi eksis, 'sang diri, harus masuk ke dalam ruang, tubuh, pikiran, dan 
pandangan sang lain. Hal ini berarti ada relasi antara hasrat 'sang diri' dengan objek yang dihasratinya, yang merupakan basis identifikasi tersebut.

Hal ini tercermin dalam fantasi pribumi yang menempati ruang 'sang lain'. Sebagai akibatnya, dalam diri pribumi/ 'sang diri' ada ruang yang terbelah dalam pemenuhan hasrat itu. Di satu sisi fantasinya berada pada tempat sang lain, di sisi lain dia berusaha untuk mempertahankan tempat yang dimilikinya. Dari dua hal tersebut pada akhirnya persoalan identifikasi bukanlah penegasan identitas yang telah terbentuk sebelumnya, bukan pula penyempurnaan 'sang diri' karena proses identifikasi memerlukan representasi subjek dalam tatanan yang berbeda dari 'sang lain'.

\section{Alienasi pada batas-batas} tertentu menghasilkan satu bentuk perlawanan yang dilakukan dengan cara mimikri ${ }^{13}$ atau peniruan. Hal

\footnotetext{
13 Konsep mimikri yang dipinjam ilmuwan sosial untuk menggambarkan proses sense of self (rasa kedirian ; kekitaan) dari ilmuwan alam bisa dilihat pada upaya binatang bunglon yang memiliki kemampuan mengubah-ubah warna kulitnya sesuai dengan habitatnya, misalnya berwarna coklat
}

tersebut disebabkan masalah pertama dari masyarakat terjajah dalam menghadapi penjajah terletak pada emansipasi, yakni peningkatan martabat diri supaya sejajar dengan kaum penjajah (Faruk, 1998: 2). Mimikri mengandung dua pengertian. Pertama, mimikri dalam kategori bahasa merupakan kemampuan jenis binatang tertentu seperti kupu-kupu untuk menyerupai jenis lain yang lebih kuat atau yang mempunyai daya pertahanan lebih besar. Kemampuan ini dapat pula berarti kemampuan mengubah warna diri menjadi seperti warna daun dan bagian tanaman lain suatu tumbuhan.

Kemampuan mimikri dapat pula berupa perubahan pigmen jenis lain, yang tidak ada kekerabatannya sama sekali. Binatang yang ditiru pigmennya biasanya lebih besar atau lebih kuat. Dengan mengadakan mimikri, si binatang bermaksud menakuti pemangsanya, sehingga akan terhindar dari bahaya (Ensiklopedi Nasional Indonesia, 1997: 313). Kedua, mimikri dalam arti istilah, yaitu imitasi dari satu

ketika berada di batang dan berwarna hijau ketika berada di daun. Tujuannya adalah menghindari kehadiran predator. 
organisme oleh organisme yang lain (Reading, 1986: 254).

Konsep mimikri atau peniruan yang dipakai oleh tokoh poskolonial seperti Homi K. Babha untuk menganalisis fenomena sosial masyarakat India pasca penjajahan Inggris mengacu pada mimikri dalam kategori bahasa. Dengan demikian, mimikri dalam konteks kolonial bisa dipahami sebagai hasrat (desire) dari subjek yang berbeda menjadi subjek "sang lain" yang hampir sama, tetapi tidak sepenuhnya. Ia hadir sebagai aktualisasi perbedaan. Mimikri dengan demikian adalah konsep yang mengandung ambivalensi, karena di satu sisi pribumi ingin membangun identitas persamaan dengan kaum penjajah, sedangkan mereka juga mempertahankan perbedaannya. Ambivalensi mimikri terlihat dalam tatanan; pertama, mimikri adalah suatu strategi yang rumit untuk menata kembali, mengatur, mendisiplinkan, dan mencocokkan diri dengan 'sang lain' sebagai visualisasi kekuatannya. Kedua, mimikri juga merupakan ketidakcocokan, sebuah perbedaan atau perlawanan yang melekat pada fungsi strategis kekuatan dominasi kolonial. Pada kenyataannya, mimikri juga mengusung paham mockery, yakni proses imitasi yang juga memiliki maksud memperolok (Bhabha, 1994: 86). ${ }^{14}$ Sikap ini juga merupakan upaya pribumi untuk mengidentifikasikan dirinya dengan kaum penjajah, antara masyarakat kecil dan penguasa.

Peniruan yang dilakukan Timur atas Barat bukan saja melalui bahasa, melainkan lebih banyak melalui gaya hidup yang menurut Adam (Faruk, 1998: 3) sebagai manifestasi dari hasrat masyarakat terjajah untuk menyesuaikan diri dengan kehendak zaman, mencapai kemajuan, dan menempatkan diri sama dengan bangsa penjajah. Menurut Macaulay (Bhabha, 1994: 87), titik persinggungan antara mempelajari Eropa dan kultur kolonial adalah

\footnotetext{
14 Mimikri yang mengusung mockery bisa dilihat pada gaya rambut dua vokalis band tanah air, yakni Ian Kasela (Radja) dan Andika (Kangen Band). Keduanya memakai gaya rambut Emo. Emo adalah gaya rambut khas pada anak-anak dengan aliran musik punk dan underground (musik keras). Lalu, yang terjadi pada Radja dan Kangen Band justru sebaliknya, yakni mengusung gaya bermusik melow dan kadang bercorak Melayu yang mendayu-dayu. Babha, dalam kasus di atas berpendapat bahwa meniru tidak berarti (sepenuhnya) mengekor, karena dalam meniru sering terkandung unsur mengejek. Jadi, meniru adalah tindakan mengagumi sekaligus melawan.
} 
kelas interpreter, yakni sebuah kelas dimana pada tubuh orang-orangnya mengalir darah India, dan warna kulitnya menunjukkan orang Timur, tetapi cita rasa, pandangan, moral, dan intektualnya adalah Barat. ${ }^{15}$

\section{Sastra dan Oposisi Mendua}

$$
\text { Karya sastra selain }
$$

merupakan hasil imajinatif dan

kreatif atau interprertatif yang kaya, juga merupakan bagian dari hubungan antara kebudayaan dan imperium. Para pengarang terlibat dalam sejarah masyarakat mereka, membentuk dan dibentuk oleh sejarah itu, serta pengalaman sosial mereka dengan kadar yang berbedabeda. Jelasnya, kebudayaan dan

\footnotetext{
15 Dalam pandangan Weberian, kelas interpreter (titik temu pandangan Marxis dan Weber) digolongkan sebagai "kelas menengah". Pada kasus Indonesia, bisa dilihat pada diri Soekarno, Hatta dan Sjahrir. Meskipun kulitnya berwarna, namun cita rasa, pandangan moral dan intelektualitasnya adalah Barat. Khususnya dalam hal memberikan corak pada identitas kebangsaan Indonesia yang sedang menggelora, Soekarno yang mendirikan Partai Nasional Indonesia pada tahun 1926 menciptakan satu trend berpakaian baru, yang oleh kacamata Kolonial Belanda dilabeli necis. Kekhasan gaya berpakaian ini terletak pada penggunaan peci (berasal dari istilah Belanda yakni phe tje yang berarti keberpihakan pada kaum tertindas) sebagai lambang nasionalisme Indonesia, dan dipadu dengan setelan safari menyerupai seragam militer tanpa dasi. Ketika soekarno menjadi presiden RI pada 18 Agustus 1945 melalui sidang PPKI I, atribut necis ditambah dengan pernik tongkat, kacamata dan bahkan kadang memegang keris.
}

estetika yang dikandungnya berasal dari pengalaman sejarah (Said, 1996b: 24). Kimmich (1996 :53) meninjau pengalaman sejarah pada pembaca seperti di bawah ini.

"Die aufgabe der literaturgeschichte ist erst dann vollendet, wenn die literarische produktion nicht allein synchron und diachron in der abfolge ihrer systeme dargestellt, sondern als besondere. Geschichte auch in dem ihr eigenen Verhältnis zu der algemeinen Geschichte gesehen wird. Dieses Verhältnis geht nicht darin auf, dass sich in der literatur aller zeiten ein typisiertes, idealisiertes, satirisches oder utopisches bild gesellschaftlichen daseins auffinden lässt. Die gesellschaftliche funktion der literatur wird erst dort in ihrer genuinen Möglichkeit manifest, wo die literarische erfahrung des lesers in den erwartungshorizont seiner Lebenspraxis eintritt, sein weltverständnis präformiert und damit auch auf sein gesellschaftliches verhalten zurückwirkt"

\footnotetext{
"Tugas sejarah sastra baru sempurna apabila karya sastra tidak hanya dipandang secara sinkronik dan diakronik dalam urutan sistemnya, tetapi juga harus dilihat sebagai sejarah khusus dalam hubungan kesatuannya dengan sejarah umum. Hubungan ini tidak berakhir dengan sekedar menemukan gambaran eksistensi sosial setiap masa yang dibuat khas, diidealkan, satirik atau utopis. Fungsi sosial sastra baru benar-benar terwujud bilamana pengalaman sastra pembaca masuk ke dalam horison harapan kehidupan praktisnya, menata pemahaman dunianya, dan memiliki pengaruh pada perilaku masyarakatnya."
} 
Karya sastra yang ditulis oleh penduduk kolonial merupakan definisi sempit dari 'novel kolonial'. Dalam arti yang lebih luas, novel kolonial adalah tulisan yang merefleksikan atau refleksi tentang kehidupan masa-masa kolonial. Novel-novel ini seringkali ditulis oleh orang Eropa yang mempunyai hubungan dengan masa lalu. ${ }^{16}$ Dari definisi ini bisa dipahami bahwa

16 Dalam sejarah Indonesia, pergulatan identitas sastra yang mendua itu mendapatkan momentum pada periode 1920an yang menandai lahirnya sastra Indonesia modern. Bentuk-bentuk representasi diri itu diwakili oleh dua golongan. Golongan pertama adalah golongan radikal, yang cenderung kekiri-kirian dalam memahami konteks penjajahan. Kepeloporannya diawali oleh R.M Tirtoadhisoerjo, lalu diikuti oleh Mas Marco Kartodikromo, Semaun, Darsono dan Tjipto Mangoenkoesoemoe. Mas Marco tercatat sebagai tokoh yang paling produktif menghasilkan tulisan. Dua karya utama yakni Mata Gelap dan Student Hidjo bisa dianggap kegalauan identitas pribumi dalam memaknai konteks modernitas yang merambah Hindia, khususnya Jawa. Golongan kedua adalah sebuah lembaga yang didirikan pemerintah kolonial sebagai respon atas produksi bacaan golongan radikal yang melabelinya sebagai "batjaan liar". Lembaga tersebut berdiri tahun 1908 dan diberi nama Commisie voor de Inlandsche School en Volkslectuur (Komisi Bacaan Rakyat). Sejak tahun 1918 berubah menjadi Kantor Bacaan Rakyat (Kantoor voor de Volkslectuur) atau Balai Pustaka. Salah seorang pengarang yang bukunya diterbitkan oleh Balai Pustaka adalah Abdoel Moeis. Kegelisahannya terhadap pribumi yang mendapat pendidikan Belanda dan dengan sendirinya mulai mengidentifikasikan diri dengan penjajahnya menjadi inspirasi bagi Moeis dalam menuangkan gagasannya menjadi roman Salah Asuhan. Roman tersebut merepresentasikan fakta sejarah yang menggambarkan bagaimana penaklukan kolonial mempunyai pengaruh terhadap kaum terjajah. tulisan tersebut merupakan 'poskolonial' yang ditulis dari luar mentalitas kolonial (Cote, 2004: 151) Ashcrofft (1995:

berpendapat bahwa sastra kolonial merupakan hasil interaksi antara kultur imperial dan kompleksitas praktik-praktik kultural pribumi. Sebagai konsekuensinya, 'teori poskolonial' jauh lebih dulu ada sebelum istilah itu sendiri dipergunakan untuk menggambarkan kultur imperial dan kompleksitas praktik-praktik kultural pribumi. Istilah poskolonial bergaung bersamaan dengan ambiguitas dan kompleksitas berbagai pengalaman kultural yang mengimplikasikannya. Hal ini menandakan bahwa poskolonial bukan merupakan akhir dari masa kolonial, melainkan dampak paling awal dari kontak dengan kolonial. Dalam kaitannya dengan studi sastra, Lo dan Gilbert (1998: 5\&9) menyatakan permasalahan pokok dalam analisis studi poskolonial meliputi bahasa, sejarah/kesejarahan, nasionalisme, kanonisitas, politik tubuh, dan ruang/tempat. Sementara itu, studi poskolonial yang menyangkut 
keagenan meliputi hibriditas, mimikri dan ambivalensi

Karena alasan-alasan kondisi poskolonial itu diawali dengan serangan ketimbang berakhirnya pendudukan kolonial (Gandhi, 2001: 4), perkembangan golongan elit baru bersama masyarakat independennya selalu didukung oleh institusi neokolonial.

Perkembangan pembagian internal didasarkan pada ras, diskriminasi bahasa atau diskriminasi agama. Perlakuan yang tidak adil dan berkelanjutan terhadap masyarakat pribumi di dalam masyarakat pemukim/settler merupakan fakta bahwa poskolonial adalah sebuah proses resistensi dan rekonstruksi yang terus menerus.

Poskolonialisme terdiri atas dua 'arsip' yang dihasilkan, pertama, subordinasi kekuasaan kolonialisme Eropa, dan kedua, melalui seperangkat praktik yang menyimpang, yang menonjol di kalangan yang menolak 'kolonialisme' (Tiffin dalam Gandhi, 2001: 277). Dalam praktiknya, poskolonial sebagai sebuah kajian produksi dan analisis budaya dibagi dalam tiga pendekatan, yaitu historis, counter discursiv, dan ekonomis. Secara historis, studi poskolonial berhubungan dengan budaya-budaya dari bangsa yang mengalami imperialisme Eropa, dan bagaimana elit pribumi melestarikan pola-pola kekuasaan dan dominasi kolonialisme, terutama pada produk budaya pascapenjajahan. Kedua, counter discursiv menunjukkan bagaimana aspek-aspek kebudayaan terjajah dalam menolak hegemoni ${ }^{17}$ atau dominasi imperialis walaupun penolakan itu tidak dalam bentuk penciptaan resistensi budaya atau mempertahankan budayanya sendiri sebagai masyarakat terjajah. Secara ekonomis, masyarakat terjajah tidak hanya berdasarkan konsepsi kebudayaan bangsa dunia ketiga, tetapi berdasarkan pada kelompok strata yang direndahkan dalam masyarakat kapitalis, yaitu mereka yang dimarginalkan baik secara ras,

\footnotetext{
17 Hegemoni merujuk pada konsep Gramsci (seorang Marxis kanan atau juga bisa disebut dengan neo-marxis) yang melakukan perluasan serta penajaman teori Karl Marx yang determinis ekonomis. Gramsci mengatakan bahwa seseorang terhegemoni (bersikap tunduk) karena dua alasan, pertama alasan "intelektual", kedua persoalan "moralitas". Kasus ini bisa dibaca pada fenomena abdi dalem kraton Jogjakarta yang digaji perbulan tidak lebih dari 50 ribu.
} 
etnis, kelas, maupun jender (Lo dan Gilbert, 1998: 1).

\section{Hibriditas, Nasionalitas ${ }^{18}$ dan Identitas}

Kultur masyarakat terjajah biasanya menggerakkan dua wacana supaya dukungan lokal menyokong nasionalisme (Lo \& Gilbert, 1998: 8).

Pertama, retorika perkembangan, yaitu sebuah pandangan ke depan yang mensyaratkan kemerdekaan dari kontrol kolonial untuk memperoleh identitas mandiri. Kedua, retorika tradisi, yakni sebuah pandangan ke belakang, yang bertumpu pada keyakinan, praktikpraktik cerita rakyat, dan gagasangagasan kaum pribumi untuk menempa ikatan antara berbagai

\footnotetext{
18 Jika merujuk pada karya Peter Sugar "Nationalism in Eastern Europe", maka nasionalisme di negara dunia III yang muncul pasca PD II seperti Indonesia dan negaranegara kawasan Afrika serta Oseania digolongkan sebagai "nasionalisme birokratis", yakni dekolonisasi negara baru dalam kerangka administratif teritorial negara yang digantikan. Hans Kohn dalam karyanya "Western and Eastern Europe Nationalism" mendefinisikan nasionalisme negara-negara di luar Eropa Barat sebagai ethnic nationalism, yakni jenis nasionalisme yang muncul sebagai reaksi terhadap negara kolonial. Implikasinya, nasionalisme jenis ini sangat bersandar pada sentimen etnis dan ingatan atau mitos-mitos bersama yang mengikat komunitas-komunitas itu. Orientasi ke masa lampau, daripada kehendak bersama menuju masa depan, lebih merupakan pelumas gerakan nasionalisme.
}

macam manusia yang membentuk masyarakat poskolonial. $^{19}$ Teori poskolonial memandang nasionalitas $^{20}$ sebagai suatu usaha untuk melahirkan tindakan afiliasi, untuk menyatukan kelompokkelompok bangsa yang terpisah di bawah tanda entitas politis, pemerintahan, dan ekonomis.

\footnotetext{
19 Pada kasus Indonesia, pasca revolusi 17 Agustus 1945, historiografi lokal yang beragam mulai diseragamkan di bawah payung historiografi nasional. Semua tokohtokoh lokal yang berjuang melawan kolonial dianggap pahlawan, bahkan dilabeli "pahlawan nasional". Dengan sendirinya, historiografi yang bercorak Nerlando sentris bergeser ke historiografi yang bercorak Indonesia sentris. Lebih dari pada itu, anakronisme sejarah yang dilakukan oleh Moh. Yamin dengan mengatakan bahwa nasionalisme Indonesia berakar sejak 6000 tahun lalu hingga pidato megalomania Soekarno yang mengatakan 3,5 abad Indonesia dijajah Belanda harus diletakkan pada kerangka jiwa jaman (zeithgeist) yang berlaku kala itu sehingga mengharuskan tindakan itu. Namun, dengan berlalunya penjajahn fisik Barat dan dimulainya penjajahan wacana atas Timur, historiografi nasional selayaknya didekonstruksi, direkonstruksi, untuk selanjutnya dikonstruksi agar sejarah yang mendekati objektif bisa dicapai.
}

20 Chaterjee mempertanyakan mengapa negara-negara Dunia Ketiga yang telah merdeka dan memiliki berbagai cita-cita kemerdekaannya, tetap tidak mampu mewujudkan cita-cita mengenai emansipasi dan kebebasan bagi warganya. Sebagian masalahnya disebabkan oleh pemposisian nasionalisme sebagai antitesa kolonialisme. Padahal, nasionalisme sebenarnya banyak menyerap nilai-nilai kolonialisme dan hanya menguntungkan kelompok elit menengah saja. Mereka ini adalah produk Barat melalui kebijakan sistem pendidikan. Akibatnya, mereka menyerap begitu banyak cara pandang Pencerahan, Chaterjee menyebutnya "konsepsi pengetahuan yang bersifat rasionalis-borjuis" (the bourgeoisrationalist conception of knowledge). 
Dalam masyarakat poskolonial, hibriditas (Ashcroft, 1995: 183) muncul sebagai akibat momen kesadaran atas penindasan kultural, yaitu ketika kekuatan kolonial menjajah untuk mengkonsolidasi kontrol politis dan ekonomis, atau ketika pemukim-penjajah menguasai orang-orang pribumi dan memaksa mereka untuk 'berasimilasi' ke dalam pola-pola masyarakat yang baru. Hibriditas muncul pada periode akhir ketika pola-pola imigrasi dari masyarakat metropolitan dan dari pengaruh wilayah imperial lainnya meneruskan memproduksi kompleksitas kultural.

Identitas pada sisi yang lain merupakan konstruksi sosial yang menyeluruh dan tidak mungkin "ada" di luar representasi dan akulturasi kultural. Tidak ada satu pun kebudayaan yang tidak menggunakan kata ganti "aku”. Akan tetapi, cara penggunaan kata ganti "aku" adalah berbeda antara kultur yang satu dan kultur yang lain. Paham kultural "aku-sang diri” di dunia Barat menggambarkan diri sebagai yang sejati, utuh, sebuah identitas yang dimiliki, dan dikenali.
Identitas diungkapkan melalui bentuk-bentuk representasi yang dapat dikenal oleh diri sendiri dan oleh orang lain. Artinya, identitas adalah suatu esensi yang dapat ditandai melaui ciri-ciri selera, kepercayaan, sikap, dan gaya hidup. Identitas dianggap sebagai personal dan sosial, yang menandai individu sebagai manusia yang sama atau berbeda dari manusia lainnya. Dengan demikian, identitas menyangkut persamaan dan perbedaan serta individual dan sosial dalam bentuk representasi.

Identitas diri ditunjang oleh kemampuan untuk mengangkat narasi tentang diri yang menyangkut perasaan kontinuitas biografis yang konsisten. Identitas menyangkut persoalan: apa yang harus dilakukan, bagaimana bertindak, ingin menjadi siapa, dan bagaimana orang lain memandang dirinya. Manusia berusaha untuk membangun narasi identitas yang koheren dengan cara sang diri membentuk suatu lintasan pengembangan masa lalu untuk mengantisipasi masa datang. Ringkasnya, identitas diri bukanlah sebuah ciri-sifat dan bukan pula 
kumpulan ciri-sifat yang dimiliki individu.

Dengan kata lain, identitas memang tidak bisa ditemukan dan ditetapkan dengan pasti. Identitas tidak pernah merupakan produk yang telah terbentuk sebelumnya, bukan pula produk yang telah selesai. Identitas diri adalah kemampuan seseorang untuk melanggengkan suatu narasi tentang diri (Barker, 2000: 165-67; Bhabha, 1994: 51). Sebagai sebuah proyek, identitas bermakna apa yang kita pikirkan sekarang dipandang dari keadaan masa lampau dan masa kini, sejalan dengan pikiran, hendak menjadi apa, yang merupakan lintasan antara harapan bagi masa depan.

\section{Franz Fanon ; Kulit Hitam Topeng Putih}

Teori mengenai identitas dikemukakan oleh Frantz Fanon dan muncul dari latar belakang kehidupannya. Fanon, yang besar di Karibia dan menyelesaikan pendidikan di Perancis sehingga bekerja sebagai seorang psikiater, terlahir dari perkawinan campuran. Ibunya orang Perancis dan ayahnya orang Algeria, yang dipandang dari kacamata kulit hitam berasal dari keluarga berada. Semenjak kecil, secara tidak langsung Fanon belajar mengenal hierarki rasisme masyarakat kolonial. Dia berada dalam kebingungan ${ }^{21}$ yang disebabkan oleh pertalian warna kulit dan status sosialnya. Tidak dapat disangkal dia adalah orang kulit putih. Akan tetapi, secara tidak sadar dia menyangsikan semua hal yang menyangkut kulit hitam dalam dirinya yang juga merupakan suatu totalitas eksistensinya (Wolter, 2003: $6)$.

Hal demikian mendorong Fanon untuk menulis sebuah buku yang diberi judul 'Schwarze Haut, weiße Masken'. Dalam karyanya ini Fanon tidak hanya membeberkan dinamika rasisme psiko sosial dan

\footnotetext{
21 Perasaan bingung ini bukan hanya dialami oleh Fanon sebagai anak hasil perkawinan Barat dan Timur, melainkan juga salah seorang tokoh Indische Partij (1912), DR. Doewes Dekker yang kemudian mengubah namanya menjadi DR. Setiabudi Danudirdja. Warna kulitnya yang tidak seputih warga totok Belanda dipertanyakan sehingga dengan sendirinya tidak mendapat pengakuan kebelandaan. Begitu pula jika ia mengidentifikasikan dirinya sebagai bumiputera ; bahwa bentuk fisiknya berbeda dengan fisik bumiputera kebanyakan. Pada akhirnya, orang-orang yang terlahir sebagai Indo berada di luar stratifikasi sosial kolonial dan dengan demikian, hak-haknya sebagai warga negara juga tidak jelas.
} 
seksual, tetapi juga mengemukakan model dialektika dasar-dasar teori pengetahuan pembebasan anti kolonial. Dia menyampaikan pengetahuan mengenai pandangan gerakan bolak-balik dalam proses subjek Barat dan sang lain sebagai terjajah.

Analisis Fanon mengenai proses identifikasi dominasi dan rasisme dilakukan dalam wilayah ambivalensi antara ras dan seksualitas, keluar dari kontradiksi yang tak pernah selesai antara kebudayaan dan kelas, perjuangan representasi fisik dan realitas sosial, pandangan dan hasrat (Bhabha, 1994: 40; Wolter, 2003: 8). Titik pusat proses identifikasi ini adalah model dialektikal 'sang diri' dan 'sang lain'. Ekspansi dalam prinsip-prinsip nasionalisasi kapitalis kolonial yang berasal dari Eropa menempatkannya pada situasi semacam itu.

Dalam masyarakat terjajah terjadi alienasi kultural yang berporos pada ambivalensi identifikasi fisik. Tatapan mata seorang kulit putih dapat memporakporandakan tubuh manusia berkulit hitam. Artinya, dalam pandangan manusia kulit putih, seorang manusia kulit hitam dipandang sebagai kanibalisme, memiliki ras yang parah dan rusak, mengalami defisiensi intelektual. Dengan sendirinya manusia kulit hitam merasa dirinya tidak hanya ditelanjangi, tetapi diamputasi, diciprati seluruh tubuhnya dengan darah hitam dan ingin menjauhkan diri dari eksistensinya. Keadaan demikian menunjukkan sebuah 'konstelasi kegilaan': orang hitam diperbudak dengan perasaan inferioritasnya, dan orang putih diperbudak oleh perasaan superioritasnya (Bhabha, 1994: 42$3)^{22}$

\footnotetext{
22 Perasaan yang dialami si kulit hitam/berwarna dari tatapan si kulit putih bisa disimak dalam otobiografi Soekarno yang ditulis oleh Cindy Adams, "Penyambung Lidah Rakyat". Ia berujar bahwa meskipun dirinya mampu melanjutkan pendidikan ke sekolah elit seperti HBS (Hogere Burgere School setelah menamatkan pendidikan di ELS (Europesche Legere School) atas dasar kemampuan bahasa Belanda yang baik didukung penguasaan ilmu pengetahuan, masih saja dipandang sebelah mata. Panggilan "Indon" dan "inlander" kerap diterima Soekarno remaja kala itu yang memiliki arti terjajah, jongos, baboe. Namun begitu, kebencian Soekarno kepada si putih atas hinaan seakan sirna ketika dihadapkan pada persoalan asmara, bahwa dirinya telah jatuh cinta kepada sahabat wanita kulit putih. Keberhasilannya memacari perempuan berkulit putih dengan sendirinya akan mengobati luka karena ejekan rasis, sekaligus mengukuhkan posisi yang setara atau bahkan mampu mengalahkan dominasi laki-laki putih.
} 
Keadaan serba tidak menyenangkan ini membuahkan tiga kondisi yang mendasari proses identifikasi dalam analisis tentang hasrat atau keinbbginan. Pertama, untuk 'mengada', seseorang harus masuk ke dalam tubuh, ke dalam cara pandang, dan ke dalam lokasi atau tempat sang lain. Kedua, ruang identifikasi yang sesungguhnya yang ada dalam tuntutan dan hasrat adalah ruang yang terbelah. Yang dimaksud terbelah di sini adalah fantasi pribumi menempati ruang sang lain/pemukim/settler. Sementara itu, pribumi tetap mempertahankan dan menjaga ruang miliknya. Kulit hitam topeng putih (schwarze Haut, weiße Masken) bukanlah pembagian yang murni. Hal ini merupakan gambaran tubuh yang digandakan, disembunyikan di dalam dua tempat dalam satu kurun waktu. Ketiga, persoalan identifikasi tidak pernah merupakan penegasan dari identitas yang telah terbentuk sebelumnya, bukan pula penyempurnaan sang diri. Tuntutan terhadap identifikasi, yaitu menjadi 'sang lain', memerlukan representasi subjek dalam tuntutan yang berbeda dari sang lain (Bhabha, 1994: 44).

\section{Kesimpulan}

Bagi wacana poskolonial, bahasa $^{23}$ merupakan landasan pokok dari perjuangan wacana poskolonial karena proses kolonisasi berawal pada bahasa. Analisis tekstual poskolonial difokuskan pada suatu cara, yakni bahasa penjajah dicocokkan, diadaptasi, dicangkokkan, dihibridasi, 'direndahkan', bahkan ditolak ke dalam proses kolonisasi. Strategi demikian dirancang untuk mencabut otoritas versi standar dari bahasa penjajah dan wacana-wacana yang menyertainya dan secara serempak mengembangkan versi lokal yang berbicara pada kemungkinankemungkinan dari konteks nonmetropolitan mereka, baik itu subjek pemukim/ settler yang harus

\footnotetext{
23 Bahasa pada masa kolonialisme menjadi unsur penting bagi terserapnya elemen penting abad renisance Eropa. Namun, perlakuan diskriminatif Belanda dan ketakutannya terhadap kesadaran diri yang dimiliki pribumi bila diajarkan bahasa Belanda mengakibatkan pengajaran bahasa Belanda dilakukan hanya pada lingkup yang sempit. Berbeda halnya dengan Prancis yang menjajah Indoncina, yang dilakukan justru sebaliknya yakni melakukan "asimilasi" kebudayaan, termasuk bahasa. Dengan demikian menjadikan pribumi sebagai orang dengan budaya Prancis.
} 
mengadaptasi bahasa mereka ke dalam tempat atau pengalaman baru, maupun subjek pribumi yang harus menamai kembali tempat atau pengalaman mereka ke dalam bahasa yang dipaksakan.

Satu dari cara-cara utama kritik poskolonial beroperasi adalah melalui pengujian sejarah atau kesejarahan. Sejarah merupakan situs kegelisahan paling utama bagi masyarakat poskolonial yang muncul untuk memberi istilah pada warisan peraturan kolonial dalam wacanawacana mengenai nasionalitas pada era pascakemerdekaan, terlepas apakah warisan itu ditolak atau disambut, atau diperlakukan secara ambivalen. Tujuan kritik poskolonial adalah untuk mengekspos jurang pemisah, ketidakhadiran, dan ambivalensi dalam representasi historis ; untuk mengidentifikasi momen perpecahan, yaitu kinerja kekuasaan imperial tidak utuh atau dikompromikan oleh perlawanan kolonial; untuk memunculkan sejarah-sejarah yang ditindas atau dilupakan (subaltern); dan juga untuk mempermasalahkan cara-cara yang lewat 'sejarah' telah ditumbuhkan otoritasnya sebagai 'kebenaran'. Proyek kritik wacana tandingan ini dapat bekerja melalui analisis dokumen historis aktual, dan, yang lebih relevan lagi bagi tujuannya adalah melalui pengujian teks-teks sastra dan kebudayaan yang dalam beberapa cara terlibat dalam proses-proses representasi historis.

Konsep 'berbeda' (liyan) dalam subjek poskolonial adalah bahwa seseorang dapat disebut sebagai 'sang lain' (the other). Hal ini dapat dirasakan secara langsung dengan cara bahwa perbedaanperbedaan superfisial dari tubuh dan suara (warna kulit, bentuk mata, jenis rambut, bentuk tubuh, bahasa, dialek atau aksen) dapat dibaca sebagai tanda-tanda yang tak terbantahkan dari inferioritas 'natural' yang mereka miliki. Kehadiran dan kesadaran tubuh dalam satu dan lain hal merupakan satu dari sekian gambaran yang merupakan pusat penolakan poskolonial terhadap eropasentris dan logosentris pada penindasan 'kehadiran', sebuah penolakan atas tanda-tanda 'tertulis' dalam ketidaksinambungan suara (lisan) dan gerak-gerik. Tubuh itu 
sendiri secara harfiah memiliki 'teks', yang di atasnya kolonisasi telah menuliskan pesan-pesan yang jelas dan dapat diteliti. Tubuh juga menjadi alat perjuangan melawan penindasan; tubuh juga merupakan simbol perjuangan dan kesempatan bagi penjajah untuk mengontrol, dan bagi terjajah untuk memiliki identitas.

\section{DAFTAR PUSTAKA}

Ashcroft, Bill, Griffiths, Garreth, and Tiffin, Helen (ed.) 1995. The Postcolonial Studies Reader. London: Routledge.

Barker, Chris. 2000. Cultural Studies, Theory and Practice. London: Sage Publications.

Bhabha, Homi. K. 1990. Nation and Narration, London: Routledge.

. 1994. The Location of

Culture, London: Routledge

Cote, Joost, dan Westerbeek, Loes (ed.) 2004. Recalling the Indies, Kebudayaan Kolonial dan Identitas Poskolonial. Yogyakarta: Syarikat.

Faruk. 1998: "Mimikri: Persoalan Post-Kolonial dalam Sastra Indonesia". Makalah Seminar Pada an International Research Workshop University of Sydney.

2002. Novel-Novel Indonesia

Tradisi Balai Pustaka 1920-

1942. Yogyakarta: Gama Media.

Gandhi, Leela. 2001. Teori Poskolonial: Upaya Meruntuhkan Hegemoni Barat. Diterjemahkan oleh Yuwan Wahyutri dan Nur Hamidah. Yogyakarta: Qalam.

Hanafi, Hassan. 2000. Oksidentalisme, Sikap Kita Terhadap Tradisi Barat, (Pengantar Dr. Komaruddin Hidayat). Jakarta: Paramadina.

Hatley, Barbara 1999. "Hibriditas, Otentisitas, dan Representasi Kewanitaan dalam Kesusastraan Indonesia Modern" "dalam Sindhunata (ed.) Menjadi Generasi PascaIndonesia Kegelisahan Y.B. Mangunwijaya. Yogyakarta: Kanisius.

Kimmich, Dorothee, Renner, R.G., und Stiegler, Bernd. 1996. Texte zur Literaturtheorie der Gegenwart. Stuttgart: Reclam

King, Richard. 2001. Agama, Orientalisme, dan Poskolonialisme (penerjemah Agung Prihantoro). Yogyakarta: Qalam

Lo, Jacqueline and Gilbert, Helen. 1998. "Poscolonial Theory: Possibilities and Limitations". Makalah pada an International Research Workshop. Sidney, May 23-31 1998. 
Mehling, Franz N. 1978. Knaurs Lexikon. München: Droemer Knaur.

Noor, Rusdian. 2002. "Mimikri dan Resistensi Radikal Pribumi terhadap Kolonialisme dalam Roman Bumi Manusia Karya Pramoedya Ananta Toer". Tesis S-2 Universitas Gadjah Mada Yogyakarta.

Poerwadarminta. 1976. Kamus Umum Bahasa Indonesia. Jakarta: Balai Pustaka

Said, Edward W. 1996a. Orientalisme (penerjemah Asep Hikmat). Bandung: Pustaka

1996b. Kebudayaan dan Kekuasaan. Membongkar Mitos Hegemoni Barat. Bandung: Mizan.

Sexl, Martin. 2004. Einfuehrung in die Literaturtheorie. Wien: WUV.

Slemon, Stephen. 1995. "The Scramble for Post-colonialism" dalam Ashcroft, Bill, Griffiths, Garreth, and Tiffin, Helen (ed.) 1995. The Postcolonial Studies Reader.

London: Routledge.

Synnott, Anthony. 2003. Tubuh Sosial, Simbolisme, Diri dan Masyarakat. Dialihbahasakan oleh Yudi Susanto. Yogyakarta: Jalasutra.

Taylor, Jean Gelman. 2004. "Identitas yang Licin: Ras, Agama, dan Identitas di Jawa Pada Abad ke -17 dan 18" dalam Cote, Joost, dan Westerbeek, Loes (ed.) 2004. Recalling the Indies, Kebudayaan Kolonial dan Identitas Poskolonial. Yogyakarta: Syarikat.

Teeuw, A. 1970, Sastera Baru Indonesia,. Kuala Lumpur: University of Malaya Press.

1980. Sastra Baru Indonesia I. Ende, Flores: Nusa Indah.

Willems, Wim. 2004. "Tidak Ada Langit Tempat Bernaung: Identitas Migran Kebangsaan Belanda dari Indonesia" dalam Cote, Joost, dan Westerbeek, Loes (ed.) 2004. Recalling the Indies, Kebudayaan Kolonial dan Identitas Poskolonial. Yogyakarta: Syarikat.

Westerbeek, Loes. 2004. "Sebuah Identitas Indies di Australia" dalam Cote, Joost, dan Westerbeek, Loes (ed.) 2004. Recalling the Indies, Kebudayaan Kolonial dan Identitas Poskolonial. Yogyakarta: Syarikat. 